\title{
Vitamin E Deficiency in the Rat
}

\section{UTERINE CHANGES IN CHRONIC DEFICIENCY}

\author{
By M. M. O. BARRIE SWEETEN, Department of Pharmacology, University of Toronto, Canada
}

(Received 28 July 1943)

1

In a previous paper [Barrie, 1938b] I described the degenerative pigmentation of the uterus produced in the rat by chronic vitamin $\mathrm{E}$ deficiency, which was first observed by Martin \& Moore [1936, 1938]. It seemed important to find out whether or not this condition could be cured, at any stage of its development, by administration of vitamin $\mathrm{E}$, and biopsies of the uterus at various stages before and during treatment have therefore been carried out.

\section{EXPERIMENTAL}

Laparotomy was performed under ether anaesthesia and a small portion of the left horn of the uterus was removed. This entailed removal of the left ovary. In one case, rat 1081, the ovary was implanted in the peritoneum. The whole operation was carried out under strictly aseptic conditions, the wound being kept as small as possible.

Twenty-nine vitamin E-deficient rats were chosen, all of which had received from the time of weaning the same vitamin E-free diet, E5 [Barrie, 1938a], but for varying periods ranging up to 10 months. The animals received daily doses of a vitamin $\mathbf{E}$ doncentrate or synthetic $d l$ - $\alpha$ tocopherol for a period of approximately 2 weeks following operation. In 18 of the rats the procedure was then repeated, the old wound being reopened and another piece of the uterus being removed; a third operation was performed on two of these animals. There was no sepsis and no deaths in any of the 49 operations.

After further treatment with vitamin $E$, the animals were mated and then killed either at the end of the resorption, or after the litter had been weaned. The last dose of vitamin $\mathbf{E}$ was always given on the day of mating.

One of the operated rats, 1081, did not become pregnant in spite of five matings with different males when it was on full oestrus. The animal was killed and a post-mortem examination was made, but no abnormality other than the uterine discoloration was found. Another animal, 1541, was exceptional in that it never came on oestrus following operation; anoestrous smears were obtained on 73 consecutive days, after which it was killed and post-mortem examination revealed a cyst on the remaining ovary.

The size and colour of the pieces of uterus removed at operation were carefully noted at the time of removal; they were then fixed in Kaiserling's fluid. The colour was restored by treatment with $1 \%(w / v)$ sodium hydrosulphite in $N / 1 \mathrm{NaOH}$, after which the pieces were washed with water and transferred to glycerine. In this way the pieces of uterus removed at different stages could be compared directly as well as by comparison of the notes made at the operations. It was found that the colour of the uterus varied from the normal pinkish white to deep chocolate

Biochem. 1943, 37 brown, and a scheme of assessment of the degree of pigmentation was drawn up as follows:

$\begin{array}{lc}\quad \text { Colour } & \text { Rating } \\ \text { Normal (pinkish white) } & \mathbf{0} \\ \text { Yellow } & \mathbf{1} \\ \text { Dark yellow or orange } & \mathbf{2} \\ \text { Orange brown } & \mathbf{3} \\ \text { Red-brown or brown } & \mathbf{4} \\ \text { Chocolate brown } & \tilde{5}\end{array}$

Most of the animals received a small dose of synthetio $d l$ - $\alpha$-tocopherol and a larger dose of vitamin $\mathrm{E}$ concentrate, $1 \mathrm{ml}$. of the concentrate being equivalent to $8.75 \mathrm{mg}$. of the $d l$ - $\alpha$-tocopherol when measured by the amount required to maintain pregnancy in vitamin E-free rats. All the doses were given on consecutive days (omitting Sundays) in the period between operations. The concentrate was given undiluted in doses of 0.25 or $0.5 \mathrm{ml}$., and the $d l$ - $\alpha$-tocopherol as a solution in sesame oil, $10 \mathrm{mg} . / \mathrm{ml}$., the daily dose being $0.25 \mathrm{ml}$.

\section{RESULTS}

Tables 1 and 2 summarize the case histories of all the rats, the animals being arranged in groups according to age. The day of the first biopsy is called day 1 , and all other stages of the experiment are given in days from this point.

The doses of vitamin $E$ given are expressed in terms of $d l$ - $\alpha$-tocopherol and the amount received between operations is given in addition to the total dose. Where there were several matings and no pregnancy ensued, the number of matings is recorded, but not the actual days of mating. In these cases the final examination was delayed as it was not considered desirable to kill the animals until it became certain that they were infertile. Where there was more than one mating before implantation took place, the day of the last mating is recorded, followed by the number of matings in brackets.

Table 3 summarizes Tables 1 and 2. The animals are again grouped according to age, but the average rating of each of these age groups has been calculated, first at the beginning of the experiment and then after treatment with vitamin $\mathbf{E}$. The results of treatment are divided into those in which treatment was followed by a successful pregnancy and those in which it was followed by resorption or birth of a dead litter. These groups are of necessity very small as they become subdivided according to response; for this reason, no statistical interpretation has been attempted. The figures give a clear indication that treatment with vitamin $\mathrm{E}$ alone has 
Table 1. The individual uterine condition, spacing of operations and time of mating, and the gestational history of vitamin $E$-deficient female rats before, during and after treatment with vitamin $E$

\begin{tabular}{|c|c|c|c|c|c|c|c|}
\hline \multirow[b]{2}{*}{ Rat no. } & \multicolumn{3}{|c|}{ Uterine condition } & \multirow{2}{*}{$\begin{array}{c}\text { Time of } \\
\text { operation } \\
\text { (day) }\end{array}$} & \multirow{2}{*}{$\begin{array}{l}\text { Time of } \\
\text { mating } \\
\text { (dav) }\end{array}$} & \multirow[b]{2}{*}{ Result of mating } & \multirow{2}{*}{$\begin{array}{c}\text { Uterine } \\
\text { condition } \\
\text { post- } \\
\text { mortem }\end{array}$} \\
\hline & Op. 1 & Op. 2 & Op. 3 & & & & \\
\hline 1137 & 5 & 4 & - & 126 & 48 & Resorption & 3 \\
\hline 1216 & 5 & $\mathbf{5}$ & 5 & 12134 & 46 & Mesorpuivil & i \\
\hline 1241 & 5 & 4 & - & 123 & 42 & Litter 1 (still-born) & 5 \\
\hline 1091 & 3 & 4 & - & 125 & 47 & Resorption & 3 \\
\hline 1541 & 3 & - & - & 1 & - & 20000 & 0 \\
\hline 1081 & 3 & 3 & - & 125 & 二 & 二 & 5 \\
\hline 1079 & 4 & 3 & - & 125 & 48 & Resorption & 1 \\
\hline 1482 & 4 & - & - & 1 & 20 (5 mates) & Litter 1 & 3 \\
\hline 1542 & 4 & - & - & 1 & 20 (10 & Resorption & 3 \\
\hline 1448 & 4 & 4 & - & 125 & 51 & Litter 3 (2 still-born) & 0 \\
\hline 1540 & 4 & - & - & 1 & 20 & $\Rightarrow \quad 5$ & 0 \\
\hline 1484 & 4 & - & - & i & 30 & Resorption & 3 \\
\hline 1904 & 5 & - & - & 1 & 20 (2 mates) & Litter 7 & 1 \\
\hline 1537 & 4 & 4 & - & 124 & 4 &,$\quad 2$ & 0 \\
\hline 1707 & 4 & 1 & - & 125 & 49 & $" 7$ & 0 \\
\hline 1539 & 2 & 3 & - & 123 & 40 & 3 & 1 \\
\hline 1538 & 3 & 3 & - & 123 & 40 & 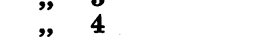 & 2 \\
\hline 1671 & 3 & 3 & - & 113 & 29 (2 mates) & Resorption & 4 \\
\hline 1668 & 2 & 2 & 3 & 11934 & 66 (5 mates) & Litter 5 & $\overline{1}$ \\
\hline 1708 & $\mathbf{0}$ & $\overline{0}$ & - & 114 & 30 & Resorption & 0 \\
\hline 1917 & 5 & - & - & $\overline{1}$ & 19 (4 mates) & Litter 6 & $\mathbf{0}$ \\
\hline 1903 & 4 & - & - & & 57 (2 mates) &,$\quad 5$ & $\mathbf{0}$ \\
\hline 1715 & 4 & 4 & - & 123 & & , 6 & 1 \\
\hline 1954 & $\overline{2}$ & - & - & $\overline{\mathbf{l}}$ & 15 & Resorption & 3 \\
\hline 1961 & 2 & - & - & 1 & 15 (3 mates) & Litter 4 & 0 \\
\hline 1844 & 2 & 2 & - & 125 & 55 &, 7 & 1 \\
\hline 1837 & 4 & 4 & - & 113 & & " 7 (1 still-born) & 0 \\
\hline 1831 & $\mathbf{2}$ & $\overline{2}$ & - & 113 & 25 (2 mates) & 3 & 3 \\
\hline 2081 & $\mathbf{0}$ & - & - & $\overline{\mathbf{l}}$ & 29 (3 mates) & $\Rightarrow 6$ & 0 \\
\hline
\end{tabular}

Table 2. The distribution and total doses of vitamin $E$ given to vitamin $E$-deficient female rats (in terms of $d l$ - $\alpha$-tocopherol), and the period on a vitamin $E$-free diet before operation

Vitamin E given (as mg. $d l$ - $\alpha$-tocopherol)

As concentrate

\begin{tabular}{|c|c|c|c|c|c|c|c|}
\hline \multirow[b]{3}{*}{ Rat no. } & \multirow[b]{3}{*}{$\begin{array}{l}\text { Months } \\
\text { on diet }\end{array}$} & \multicolumn{3}{|c|}{ As c } & \multirow{3}{*}{$\begin{array}{l}\text { As tocopherol } \\
\text { on day } \\
\text { of mating }\end{array}$} & \multicolumn{2}{|c|}{ Total dose } \\
\hline & & \multirow{2}{*}{$\begin{array}{l}\text { Between } \\
\text { Op. } 1 \\
\text { and Op. } 2\end{array}$} & \multirow{2}{*}{$\begin{array}{c}\text { Between } \\
\text { Op. } 2 \\
\text { and Op. } 3\end{array}$} & \multirow{2}{*}{$\begin{array}{l}\text { Between } \\
\text { last Op. } \\
\text { and mating }\end{array}$} & & & \\
\hline & & & & & & $\begin{array}{l}\text { As con- } \\
\text { centrate }\end{array}$ & $\begin{array}{c}\text { As } d l-\alpha- \\
\text { tocopherol }\end{array}$ \\
\hline 1137 & 10 & 35 & - & 40 & 5 & 75 & 5 \\
\hline 1216 & 10 & 96 & $15^{*}$ & 0 & 5 & 96 & 20 \\
\hline 1241 & 9 & 88 & - & 0 & 5 & 88 & 5 \\
\hline 1091 & 8 & 35 & - & 40 & 5 & 75 & 5 \\
\hline 1541 & 8 & - & - & 61 & - & 61 & - \\
\hline 1081 & 8 & 70 & - & 0 & - & 70 & - \\
\hline 1079 & 8 & 35 & - & 40 & 5 & 75 & 5 \\
\hline 1482 & 8 & - & - & 66 & 5 & 66 & 5 \\
\hline 1542 & 8 & - & - & 61 & 5 & 61 & 5 \\
\hline 1448 & 8 & 35 & - & 40 & 5 & 75 & 5 \\
\hline 1540 & 8 & - & - & 61 & 5 & 61 & 5 \\
\hline 1484 & 8 & - & - & 61 & 5 & 61 & 5 \\
\hline 1904 & 7 & 一 & 一 & 48 & 5 & 48 & 5 \\
\hline 1537 & 7 & - & - & 83 & 5 & 83 & 5 \\
\hline 1707 & 7 & 35 & - & 40 & 5 & 75 & 5 \\
\hline 1539 & 7 & 83 & - & 0 & 5 & 83 & 5 \\
\hline 1538 & 7 & 83 & - & 0 & 5 & 83 & 5 \\
\hline 1671 & 7 & 35 & - & 57 & 5 & 92 & 5 \\
\hline 1668 & 6 & $10^{*}$ & 96 & 0 & 5 & 96 & 15 \\
\hline 1708 & 6 & 92 & - & 0 & 5 & 92 & 5 \\
\hline 1917 & 6 & - & - & 48 & 5 & 48 & 5 \\
\hline 1903 & 6 & - & - & 48 & 5 & 48 & 5 \\
\hline 1715 & 6 & 88 & - & 0 & 5 & 88 & 5 \\
\hline 1954 & 6 & - & - & 48 & 5 & 48 & 5 \\
\hline 1961 & 6 & - & - & 105 & 5 & 105 & 5 \\
\hline 1844 & 5 & 44 & - & 30 & 5 & 74 & 5 \\
\hline 1837 & 5 & 92 & - & 0 & 5 & 92 & 5 \\
\hline 1831 & 5 & 92 & - & 0 & 5 & 92 & 5 \\
\hline 2081 & 4 & - & - & 83 & 5 & .83 & 5 \\
\hline
\end{tabular}

* These doses were $d l$ - $\alpha$-tocopherol. 
Table 3. The average effect of treatment with vitamin $E$ on the uterine colour rating of vitamin $E$-deficient rats treated after varying periods on a vitamin $E$-free diet

\begin{tabular}{|c|c|c|c|c|c|c|c|c|}
\hline $\begin{array}{l}\text { Months } \\
\text { on diet }\end{array}$ & $\begin{array}{l}\text { Average } \\
\text { rating }\end{array}$ & $\begin{array}{l}\text { No. } \\
\text { of rats }\end{array}$ & $\begin{array}{c}\text { Average } \\
\text { rating after } \\
\text { treatment }\end{array}$ & $\begin{array}{c}\text { No. } \\
\text { of rats }\end{array}$ & $\begin{array}{c}\text { Average } \\
\text { rating after } \\
\text { pregnancy }\end{array}$ & $\begin{array}{l}\text { No. } \\
\text { of rats }\end{array}$ & $\begin{array}{c}\text { Average } \\
\text { rating after } \\
\text { resorption }\end{array}$ & $\begin{array}{l}\text { No. } \\
\text { of rats }\end{array}$ \\
\hline 4 & 0.0 & 1 & $\overline{9.7}$ & $\overline{3}$ & 0.0 & 1 & - & - \\
\hline $\begin{array}{l}5 \\
6\end{array}$ & $\begin{array}{l}2 \cdot 7 \\
2 \cdot 7\end{array}$ & $\begin{array}{l}3 \\
7\end{array}$ & $\begin{array}{l}2 \cdot 7 \\
2 \cdot 2\end{array}$ & $\begin{array}{l}\mathbf{3} \\
\mathbf{3}\end{array}$ & $\begin{array}{l}1.3 \\
0.4\end{array}$ & $\begin{array}{l}3 \\
5\end{array}$ & $\overline{1.5}$ & $\overline{2}$ \\
\hline 7 & $3 \cdot 5$ & 6 & $2 \cdot 8$ & 5 & 0.8 & 5 & $4 \cdot 0$ & $\overline{1}$ \\
\hline 8 & $3 \cdot 7$ & 9 & $3 \cdot 5$ & 4 & $1 \cdot 0$ & 3 & $2 \cdot 5$ & 4 \\
\hline 9 & $5 \cdot 0$ & 1 & $4 \cdot 0$ & $\cdot 1$ & - & - & $5 \cdot 0$ & 1 \\
\hline 10 & $5 \cdot 0$ & 2 & $4 \cdot 5$ & 2 & - & - & $2 \cdot 0$ & 2 \\
\hline Overall averages & $3 \quad 3 \cdot 3$ & 29 & $3 \cdot 1$ & 18 & $0 \cdot 75$ & 17 & $2 \cdot 6$ & 10 \\
\hline
\end{tabular}

very little effect on the uterine discoloration, the rating being reduced from $3 \cdot 3$ to $3 \cdot 1$, a reduction which obviously has no significance, whereas the same treatment followed by pregnancy and the birth of a living litter reduces the rating to 0.75 , which must be considered significant, even on the small amount of available data. On the other hand, treatment with vitamin $\mathrm{E}$ followed by a gestation

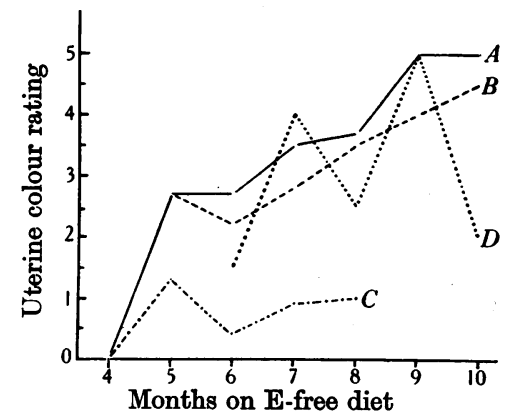

Fig. 1. Uterine colour rating before and after treatment with vitamin E. Curve $A$, before treatment. Curve $B$, after treatment. Curve $C$, after treatment and successful gestation. Curve $\dot{D}$, after treatment and resorption, or unsuccessful gestation.

in which resorption occurred reduces the rating only to $2 \cdot 6$. In each treated group an improvement was obtained; this was only $\mathbf{0 . 2}$ after vitamin $E$ treatment, $\mathbf{0 . 7}$ after vitamin $\mathrm{E}$ treatment and resorption, but 2.5 after vitamin $E$ treatment and a successful gestation. A similar comparison can be obtained by considering the different age groups separately, but owing to the small number of animals, it would seem better to consider the averages of these groups. Fig. 1 clarifies this point by expressing the result graphically.

\section{DISCUSSION}

It appears clear from these results that the uterine discoloration produced by chronic vitamin $\mathbf{E}$ de- ficiency is a reversible condition, but that administration of vitamin $\mathbf{E}$ alone, even if given in massive doses, will have very little effect unless the animal is mated and gestation ensues. If the gestation is normal and a live litter results there is a marked, and in many cases, complete recovery from the pigmented condition. If a resorption gestation occurs the improvement is much less. It seoms probable that pregnancy increases the circulation in the uterine muscle and is therefore the chief factor in the removal of the pigment.

Unfortunately, it is impossible to control the experiment by producing pregnancy and giving no vitamin $\mathbf{E}$, as sterility is well established before the onset of pigmentation. It can only be shown that vitamin $\mathbf{E}$ alone is ineffective.

These results agree very well with those of Martin \& Moore [1939], who found very similar uterine discolorations in their vitamin E-deficient rats. Unfortunately they did not examine the uteri before and after treatment, so that their results cannot be conclusive. These authors also say that after parturition the uterus of such rats remains abnormal, but since there was no previous examination, there is nothing to show that improvement has not taken place, and the foregoing experiments indicate that this was probably the case.

\section{SUMMARY}

1. Chronic vitamin $\mathbf{E}$ deficiency in the female rat produces uterine discoloration.

2. This discoloration is not curable by vitamin $\mathbf{E}$ administration alone, but yields to this treatment if accompanied by successful pregnancy.

3. It is suggested that the increased circulation to the uterine muscle during pregnancy is responsible for the removal of the pigment.

I wish to thank the Directors of the British Drug Houses Ltd., for permission to publish this work which was carried out while I was working in their laboratories.

\section{REFERENCES}

Barrie, M. M. O. [1938a]. Biochem. J. 32, 1467.

$-[1938 b]$. Biochem. J. 32, 2134.

Martin, A. J. P. \& Moore, T. [1936]. Chem. Industr. 55, 236. [1938]. Chem. Industr. 57, 973.
Martin, A.J. P. \& Moore, T. [1939]. In Physiological Action of Vitamin Eand Consequences of Vitamin-EDeficiency. Symposium of the Food Group, Society Chemical Industry. London: Society Chemical Industry. 